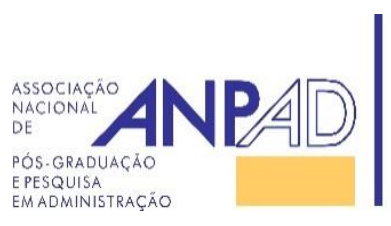
Available online at http://www.anpad.org.br/bar
BAR, Rio de Janeiro, v. 13, n. 3, art. 3, e160025, July/Sept. 2016
http://dx.doi.org/10.1590/1807-7692bar2016160025

\title{
Interpartner Differences and Governance Mode Dilemma: The Role of Alliance Scope
}




\begin{abstract}
It is generally recognized that the governance structure of an alliance, equity versus nonequity, is an important strategic choice. Since an alliance teams up companies that are inevitably divergent in upstream resource endowment and/or downstream market coverage, it is necessary to select an appropriate governance form to manage the interpartner differences and thus facilitate cooperation. Nevertheless, prior studies have suggested conflicting governance modes despite their adherence to the rationale of transaction cost economics. To address this gap in extant literature, the current study takes into account the moderation of alliance scope in the interfirm difference-governance choice linkage. In sum, this paper argues that, to determine a suitable governance structure, there is a need to concurrently examine how different the partnering firms are from each other and what range the collective activities cover. Hierarchical logistic regression analysis was used to test hypotheses in a sample of 125 bilateral alliances. The empirical findings indicate that nonequity modes will be preferred for the alliances that have less interfirm resource disparity and narrower alliance scopes, while equity-based forms will be chosen for the alliances that have less interfirm market divergence and narrower alliance scopes.
\end{abstract}

Key words: strategic alliance; interfirm difference; alliance scope; alliance form; governance mode. 


\section{Introduction}

Forming alliances has been a popular strategy among firms over the past two decades (Kayo, Kimura, Patrocínio, \& Oliveira, 2010; Lazzarini, Brito, \& Chaddad, 2013; Lioukas, Reuer, \& Zollo, 2016; Silva, Dacorso, Costa, \& Di Serio, 2016), and since then substantial attention has been drawn to the selection of an appropriate governance form, in particular the equity versus nonequity modes (Choi \& Contractor, 2016; Colombo, 2003; García-Canal, Valdés-Llaneza, \& Sánchez-Lorda, 2014). Simply put, an equity alliance refers to a new jointly-financed and managed entity that allying firms create, while a nonequity alliance is a contractual agreement without setting up a separate legal entity in the cooperation (Pisano, 1989; Oxley, 1999). The strategic choice is an important one, in that an alliance will team up two or more firms that are divergent, more or less, with regard to their upstream resource endowment and/or downstream market coverage (Das \& Teng, 2003; Kim \& Parkhe, 2009). To bridge interpartner differences and facilitate cooperation, it is thus necessary to opt for a suitable governance structure to organize collaborative activities (Mayer \& Salomon, 2006).

Indeed, transaction cost economics provides the guideline that an equity alliance should be formed if the partnership is exposed to greater risks of opportunism and contractual hazards (e.g., Judge \& Dooley, 2006), which are primarily shaped by the degree of asset specificity, observability, and appropriability. Despite adherence to this tenet, prior studies have seemed to prescribe conflicting governance modes to manage the interfirm differences. For instance, several scholars have claimed that a large interpartner divergence increases causal ambiguity, owing to possible deficiencies of expertise in each other's field, and raises concerns about the low value of the committed assets for other uses (Colombo, 2003; Simonin, 1999). To enhance mutual understanding and restrain holdup problems, it is necessary to establish an equity alliance that has incentive alignment properties of shared ownership and offers better monitoring mechanisms brought about by the formal managerial hierarchy. On the other hand, significant differences between partnering firms can curb absorptive capacity and alleviate the risk of unintended knowledge leakage (Oxley, 1997; Sampson, 2004), as such, the minor appropriability threat points to a preference for adopting a nonequity alliance. Therefore, partner dissimilarity may lead to a trade-off among contractual hazards, and it becomes unclear whether equity or nonequity alliances are more suitable.

This governance choice dilemma with regard to managing interpartner differences has, perhaps surprisingly, been underexplored in the literature thus far. Through exploiting interfirm similarity or dissimilarity, alliance participants accomplish such goals as consolidation of extant capacity or development of new capabilities (Tyler \& Caner, 2016) which involves the issue of whether to restrict or extend joint activities to certain fields (referred to hereafter as alliance scope). As previous research noted that alliance scope also plays a crucial role in influencing the probability of partners' opportunism (Oxley, 1997; Oxley \& Sampson, 2004), it is essential to take into account the contingency of alliance scope in the interpartner difference-governance choice relationship.

In determining an appropriate collaborative form, this study seeks to address gaps in prior research by concurrently considering how disparate partnering firms are from each other and how vast is the domain of collective activities that are performed. In the next section, we review the relevant literature and develop a set of hypotheses. We then explain our research methods, including the sample, data sources, and measurements. After reporting the results, we discuss the theoretical and managerial implications of this research, and suggest directions for future work.

\section{Literature and Hypotheses}

This section begins by delineating the primary contractual hazards brought by the opportunism of interpartner collaboration (namely the holdup, observability, and appropriability problems), and 
reviewing the governance forms prescribed by prior studies to mitigate contractual hazards. Then, we introduce the moderating effect of alliance scope in the relationship between interfirm differences and governance form decision, and develop hypotheses to address the inconsistent mode choices in the extant literature.

\section{Contractual hazards and the dilemma of governance-form choice}

Through exploiting similarity or exploring dissimilarity in resource endowment and/or market coverage between partners, firms gain efficiencies or synergies that are not attainable when operating alone (Hoetker \& Mellewigt, 2009; Mitchell, Dussauge, \& Garrette, 2002). On the path to accomplishing such goals, however, transaction cost economics raises the concern of opportunism (Das, 2006; Holloway \& Parmigiani, 2016; J. Lee, Hoetker, \& Qualls, 2015; Williamson, 1975, 1985), arising primarily from such contractual hazards as the holdup, observability, and appropriability problems (Mayer \& Salomon, 2006).

Holdup refers to the condition in which the commitment that one firm dedicates to the alliance is of little value in other contexts (Williamson, 1985). This sunk investment would lock the firm into the cooperation, and it thus becomes vulnerable to expropriation by partners attempting to extract excessive rents. By corollary, the magnitude of the holdup risk is associated with the specificity of the assets committed to the partnership, and high asset specificity represents that an asset is worth less if deployed in another use or for another user (Klein, Crawford, \& Alchian, 1978). Alliance participants are not subject to a holdup threat if the asset can be employed in other activities or in collaboration with other partners without losing its value.

Observability concerns how easy it is to assess the quality of partners' actions and measure collaborative outcomes (Holmstrom, 1979). A high difficulty in verifying whether partners have lived up to their contractual obligations provides them with incentives to shirk their contracted responsibilities. The situation that one party's behaviors are not observable by the counterparty to the contract is related particularly to information asymmetry in which one party knows more than the other and fails to credibly communicate the information to its collaborators (Akerlof, 1970). Imperfect observability of partners' behaviors makes it problematic to enforce contracts and appraise partners' contributions to the shared goal.

Appropriability is a contractual hazard of leaking valuable intellectual property in ways that are not intended in the agreements (Gulati \& Singh, 1998; Oxley, 1997; Teece, 1986). This is detrimental to the firms owning this property, because they forfeit their exclusive right to a rent-generating asset and fail to capture a fair share of rents from the collaboration in which they are engaged (Mayer \& Salomon, 2006). Worse still, partners may re-deploy the acquired assets to areas beyond the scope of the current alliance, adversely impacting the focal firms' competitive position (Colombo, 2003). Because successful completion of alliance objectives often demands participants to exchange sufficient knowledge with each other, it is difficult to prevent undesired spillovers of proprietary assets (Davis, in press).

To alleviate the above contractual hazards in alliances, many scholars have proposed different forms of governance, particularly in relation to the choice of an equity versus a nonequity structure (e.g., Colombo, 2003; Mayer \& Salomon, 2006; N. Li, Boulding, \& Staelin, 2010; Pangarkar \& Klein, 2001). An equity-based alliance, or a so-called joint venture, is a new legal entity jointly created by two or more firms who share equity and management control over the cooperation, whereas a nonequity alliance pools together allying firms' resources and/or capabilities without involving equity sharing (Osborn \& Baughn, 1990; Oxley, 1997). Unlike nonequity modes, equity-based governance structures enable each participant to effectively post a bond equal to its equity share, and the ongoing returns to each partner are based on the profits of the venture as a whole. Further, compared with nonequity modes, equity alliances have governance attributes closer to those of an internal organization, such as authority, command, and incentive systems. 
The logic of transaction cost economics suggests that, when contractual hazards are severe, an equity alliance would be preferred. The ownership control and share in the profits or losses of such ventures' performance better align the incentives of the parent firms, thus mitigating opportunistic behaviors (Hennart, 1988). Moreover, the hierarchical elements provide an effective means of dispute resolution and task coordination between partners (Gulati \& Singh, 1998). Besides, Oxley (1997) and Sampson (2004) indicated that equity alliances usually have a joint board of directors composed of members from all partnering firms, which offers a superior monitoring mechanism and access to partnering information. Although an equity-based structure is effective in attenuating opportunism and contractual hazards, this type of cooperative mode is subject to higher administrative and bureaucratic costs, as opposed to nonequity alliances. Hence, when it is not cumbersome to draft a contract against contractors' incentive to shirk, nonequity alliances may be a better choice (Reuer \& Devarakonda, 2016).

Although there is some consensus among transaction cost theorists with regard to managing high contractual hazards with equity alliances, and low contractual hazards with nonequity alliances, the issue of partner discrepancy can lead to contrasting changes in contractual hazards. For the partnerships in which there is a wide gap between allying firms' resource endowments and/or market coverage, both holdup and observability problems would be severe. Because of idiosyncratic resource strengths and market knowledge about respective competitive domains, allying firms are bound to make substantial investments to support and facilitate the cooperation. Such investments may be relation-specific, given that the value is likely to be appreciably lower for other uses than within the focal transaction between the two parties (Holmstrom \& Roberts, 1998). More than this, partner discrepancy renders it onerous for firms to understand and value the great variety of information related to the cooperation. Nevertheless, the appropriability hazard might be lessened because competencies in different spheres diminish partnering firms' absorptive capacity with regard to identifying, assimilating, and exploiting knowledge from each other (Cohen \& Levinthal, 1990). Although there may be more for the partnering firms to learn from each other in this situation, Sampson (2004) has pointed that learning is a far cry from knowledge sharing, let alone knowledge appropriation.

In contrast, when partners are commensurate in their resource endowments and/or market coverage, they are more likely to be in a state of competitive interdependence, in which they compete for scarce inputs and outputs (Hannan \& Freeman, 1977). In this situation, the transferability of their knowledge between each other is potentially high, so that their dedication to the collaborative relationship is less likely to be subject to that transaction, preventing one party from being held up by the other. In addition, the problem of information asymmetry is significantly reduced in this context, because the partnering firms' similarities naturally generate knowledge about each other (Wang \& Zajac, 2007), so they are less subject to the observability hazard. However, this situation exposes firms' expertise to the risk of being exploited and making partners, which may even be existing competitors, stronger through knowledge transfer and market access (Kogut, 1988). Table 1 summarizes the above discussion.

Table 1

\section{Interfirm Differences and the Dilemma of Alliance Mode Choice}

\begin{tabular}{|c|c|c|c|c|}
\hline \multirow{2}{*}{\multicolumn{2}{|c|}{ Interfirm Differences }} & \multicolumn{2}{|c|}{ Contractual Hazards } & \multirow[b]{2}{*}{ Alliance Mode } \\
\hline & & Holdup Problem & & \\
\hline \multirow{2}{*}{$\begin{array}{l}\text { - Resource Disparity } \\
\text { - Market Divergence }\end{array}$} & Large & High & Low & Undetermined \\
\hline & Small & Low & High & Undetermined \\
\hline
\end{tabular}




\section{Contingency of alliance scope}

Simply put, interpartner differences in upstream resource allocation and/or downstream market position lead to inconsistent changes in the holdup, observability, and appropriability problems. That is, more (less) interpartner discrepancy leads to more (less) holdup and observability concerns, yet less (more) appropriability threat. As a consequence, it is problematic to determine a proper alliance mode. However, taking alliance scope into consideration is of interest in this context, and will be conducive to making a better alliance governance choice.

Alliance scope refers to the extent to which partners agree to combine multiple functions or value chain activities (e.g., R\&D, manufacturing, and/or marketing) during the tenure of the collaboration (Oxley \& Sampson, 2004; Varadarajan \& Cunningham, 1995). An increase in alliance scope represents a wider range of activities involved in the partnership. Owing to the great complexity and uncertainty of cooperative relationships, the extent of alliance scope further complicates contract stipulation and enforcement, and hence potentially influences the risks of opportunism caused by interfirm differences and the subsequent governance decision.

Because of the more extensive activities performed in the cooperation, an alliance with a broader scope demands more points of contact between partners in order to proceed with joint operations in a successful manner. As the proprietary resources and knowledge embedded in daily routines are greatly exposed to partners under this circumstance, protection of these assets becomes more challenging (Teece, 1992). Moreover, since daily operational routines often exhibit great inseparability of knowledge in multifarious ways, it is difficult to carve out the boundary of information flows to be carried out across organizations (Oxley \& Sampson, 2004; Singh, Kryscynski, Li, \& Gopal, 2016). These concerns exacerbate the appropriability hazard for the cooperation with less interpartner resource disparity and/or market divergence, but are less severe in the partnerships with larger interfirm resource and market differences given low absorptive capacity, as aforementioned.

In comparison, a narrow alliance scope confines cooperation to a specific, more defined area, without disclosing other valuable information. As a consequence, such alliances limit partners' access to the proprietary assets that are not supposed to be exposed and expropriated (D. Li, Eden, Hitt, \& Ireland, 2008). Furthermore, such focused attention on a certain cooperative dimension renders it easier for firms to modularize their resources and capabilities to be used in the alliance, while keeping most other parts intact. This practice, on the one hand, protects valuable resources and know-how against unwanted spillover, yet, on the other hand, facilitates the intended knowledge sharing and learning because of the concrete, better-specified content of focal knowledge. Hence, for alliances with small interpartner differences, a narrow alliance scope serves to control information flow and impede leakage of competitive intelligence, thus reducing the appropriability hazard. In contrast, a narrow alliance scope offers partnering firms with distinct resource and market strengths an adequate platform through which a well-specified domain of information exchange expedites procurement of the focal knowledge and elevates partners' ability to appropriate the knowledge elsewhere.

With respect to the holdup and observability hazards, a broad alliance scope worsens these two problems in cases of both large and small interpartner discrepancies. When partnering firms engage collectively in multiple areas of activities, a greater extent of coordination is required in the alliance. Although closer contacts may be conducive to the enhancement of mutual understanding, more conflicts are also likely to arise (Oxley \& Sampson, 2004). Partnering firms are thus more likely to make investments that are specific to that relationship so as to facilitate joint actions. Along this course, because such cooperation involves greater complication of joint tasks, observability of partners' behaviours and alliance outcomes decreases. In contrast, a narrow alliance scope mitigates the two concerns.

Taken together, Table 2 illustrates the alliance structures preferred in managing the holdup, observability, and appropriability hazards. When there is a broad alliance scope, all three risks become more severe in the case of smaller interpartner differences, therefore increasing the odds of selecting an equity-based alliance. When there is a narrow alliance scope, smaller interpartner differences lead to 
the selection of a nonequity alliance, as the three concerns are all mitigated. Interestingly, the three threats change in the opposite directions for large interpartner differences when the alliance scope is either broad or narrow. However, this trend does not signify an undetermined governance form.

Table 2

Moderation of Alliance Scope

\begin{tabular}{|c|c|c|c|c|}
\hline \multirow{2}{*}{\multicolumn{2}{|c|}{ Interfirm Differences }} & \multicolumn{2}{|c|}{ Contractual Hazards } & \multirow[b]{2}{*}{ Alliance Mode } \\
\hline & & Holdup Problem & Annronriobility & \\
\hline \multirow{4}{*}{$\begin{array}{l}\text { - Resource Disparity } \\
\text { - Market Divergence }\end{array}$} & \multirow{2}{*}{ Large } & Broad Scope: $\uparrow$ & Broad Scope: $\downarrow$ & Nonequity \\
\hline & & Narrow Scope: $\downarrow$ & Narrow Scope: $\uparrow$ & Equity-based \\
\hline & \multirow{2}{*}{ Small } & Broad Scope: $\uparrow$ & Broad Scope: $\uparrow$ & Equity-based \\
\hline & & Narrow Scope: $\downarrow$ & Narrow Scope: $\downarrow$ & Nonequity \\
\hline
\end{tabular}

Prior alliance-scope studies have shed most light on the anxiety of leaking proprietary knowledge and turning partners into future competitors (e.g., Khanna, Gulati, \& Nohria, 1998; Oxley \& Sampson, 2004), alluding to the greater ramifications of appropriability than those of the other two hazards. It is thus proposed herein that, with a broad alliance scope, the declining appropriability threat outweighs the rising holdup and observability risks for large interfirm discrepancies, leading to preference for a nonequity mode of cooperation. When the alliance scope is narrow, large interfirm discrepancies introduce a greater appropriability hazard which exceeds the falling holdup and observability problems, rendering an equity mode more favourable. Overall, our hypotheses are stated as follows:

H1: Other things being equal, larger interfirm resource disparity is likely to lead to the choice of an equity-based over a nonequity alliance for a narrower alliance scope, yet the opposite choice is likely to be made when the alliance scope is broader.

H2: Other things being equal, larger interfirm market divergence is likely to lead to the choice of an equity-based over a nonequity alliance for a narrower alliance scope, yet the opposite choice is likely to be made when the alliance scope is broader.

\section{Methods}

\section{The sample}

We tested our hypotheses on a sample of alliances (equity and nonequity modes) compiled from the Securities Data Company (SDC), a database used extensively in extant alliance research (e.g., Arikan \& Shenkar, 2013; Kim \& Parkhe, 2009; Oxley \& Sampson, 2004). Construction of our empirical setting involved several steps. First, we gathered the alliance relationships that were established during the ten years between January $1^{\text {st }}, 2000$, and December $31^{\text {st }}, 2009$, as reported in the SDC database. Our choice of such a time frame is to capture the allying conditions that have prevailed in recent years. Second, we restricted these alliances to those with only two partners, due to concerns with regard to our dyadic measures (D. Li et al., 2008). Third, we retained only the alliances in which both partners are public firms (because of data availability) and have full sets of the financial data of interest in the COMPUSTAT database. This sampling procedure resulted in a final sample size of 125 alliances.

We collected data from several sources. Specifically, we utilized information provided in the SDC database to determine the alliance mode (equity versus nonequity form), alliance location, and 
prior experience of cooperation between the two partnering firms. We employed information from the COMPUSTAT database to evaluate interfirm differences in both resource disparity and market divergence. To determine how broad the alliance scope is, we cross-verified the references that SDC provided in identifying these alliances, supplemented by press releases published in media outlets through the Wall Street Journal and the LexisNexis databases. Inter-rater reliability was checked to ensure consistency with regard to alliance scope across two raters. For the data on national cultural distance, we drew on Hofstede's dimensions of national culture (1980).

\section{The model}

We analyzed our data through hierarchical logistic regression models. This estimation allows us to compare the restricted regression model (without the interaction terms) to the full regression model so as to assess the posited moderating effects. Sequentially, we entered control variables, predictors, and interaction terms into hierarchical regression models, which were designed to assess the incremental explanatory power of the added variables. We illustrate the three equations that are used to test the hypothesized relationships below:

. Step 1: $R_{i}=\alpha_{i}+\beta_{1}$ Controls $_{i}+\varepsilon_{i}$

. Step 2: $R_{i}=\alpha_{i}+\beta_{1}$ Controls $_{i}+\beta_{2} \mathrm{AS}_{i}+\beta_{3} \mathrm{RD}_{i}+\beta_{4} \mathrm{MD}_{i}+\varepsilon_{i}$

. Step 3: $R_{i}=\alpha_{i}+\beta_{1}$ Controls $_{i}+\beta_{2} \mathrm{AS}_{i}+\beta_{3} \mathrm{RD}_{i}+\beta_{4} \mathrm{MD}_{i}+\beta_{5} \mathrm{AS}_{i} \times \mathrm{RD}_{i}+\beta_{6} \mathrm{AS}_{i} \times \mathrm{MD}_{i}+\varepsilon_{i}$

where R captures the probability of choosing an equity-based as opposed to a nonequity mode; Controls are a set of alliance and interpartner attributes that may also affect the choice between an equity and a nonequity alliance; $\mathrm{AS}, \mathrm{RD}$, and MD stand for alliance scope, resource disparity, and market divergence, respectively.

\section{Measures}

Alliance mode choice. The dependent variable is a binary variable, coded $\mathbf{1}$ for an alliance using an equity-based governance structure (i.e. joint venture) and $\mathbf{0}$ for a nonequity mode. Consistent with previous studies (e.g., Oxley, 1999; Pangarkar \& Klein, 2001), alliances are classified into the equitybased category if partners created a joint venture and the nonequity regime if there were no equity commitments. The SDC database provided information on whether an alliance involved the creation of a joint venture. Because of the binary nature of our dependent variable, we used binomial logistic regression to test our hypotheses.

Resource disparity. Previous alliance research that examined interfirm resource differences has mainly focused on R\&D, operation, and marketing-related resources (Dyer, 1996; Polidoro, Ahuja, \& Mitchell, 2011). We thus examined resource disparity between partners in these three dimensions. Following prior studies that assessed interfirm differences by the Euclidean distance (e.g., Polidoro et al., 2011; Yang, Lin, \& Lin, 2010), we evaluated resource disparity between a pair of firms in alliances along the three aspects that were captured by widely used measures, including R\&D expense, cost of goods sold, and marketing expense. More specifically, we calculated a three-year average for each type of resources that an alliance participant possessed, deflated by its three-year average sales, before the year when an alliance was formed. The reason for taking the average is to smooth out abnormal fluctuations in an unusual calendar year (Diestre \& Rajagopalan, 2011; Shen \& Cannella, 2002), using the deflation is to reduce firm size impact (Stern, Dukerich, \& Zajac, 2014), and taking a time lag to the alliance formation is to better reflect the causality direction (Gulati, Lavie, \& Singh, 2009). The data used for this calculation was extracted from the COMPUSTAT database. This measure is shown algebraically as follows:

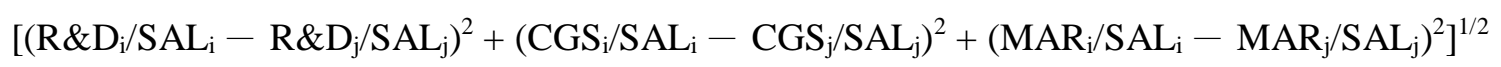


where R\&D, SAL, CGS, and MAR represent the three-year average of R\&D expenses, total sales, cost of goods sold, and marketing expenses, respectively, for alliance participants firm $i$ and firm $j$.

Market divergence. The difference in market segments to which each partner's core business and product line belong reflects the market divergence between the two partners. Complying with many prior studies that measured a firm's market segment by standard industrial classification (SIC) (e.g., G. K. Lee \& Lieberman, 2010; Pehrsson, 2006), we used SIC codes extracted from the COMPUSTAT database and compared between partnering firms. Specifically, the level of market divergence runs the gamut from zero to four, where $\mathbf{0}$ signifies the lowest market divergence when both partners have identical four-digit SIC codes, $\mathbf{1}$ for the same first three digits, $\mathbf{2}$ for the same first two digits, $\mathbf{3}$ for the same first digit, and $\mathbf{4}$ for totally different four-digit SIC codes.

Alliance scope. Extending from prior research (D. Li et al., 2008; Oxley \& Sampson, 2004), we gauged the scope of collaborative activities performed in alliances by analyzing how many types of activities (including technological, manufacturing, marketing, and financial) were involved. As such, this variable ranges from one to four, where 1 represents the narrowest scope when an alliance entailed only one area of cooperative activity, and $\mathbf{4}$ denotes the broadest scope when all four activities were involved. To determine the extent of alliance scope, we content-analyzed the description of each alliance provided in the SDC database, supplemented by press releases in such sources as the Wall Street Journal and the LexisNexis databases. The inter-rater reliability was examined and found a high level of correspondence between two raters $(r=0.92, p \leq 0.01)$.

Control variables. We controlled for three variables that have been closely linked to alliance mode choice in previous studies, namely alliance location (e.g., Ang \& Michailova, 2008), prior cooperative ties between the two partners (e.g., Colombo, 2003), and their national cultural distance (e.g., Pangarkar \& Klein, 2001). Alliance location was measured by a dummy variable, coded $\mathbf{1}$ for the alliance venue outside the partnering firms' home countries and $\mathbf{0}$ for the location in one of the partners' home countries. Previous experience of cooperation between the two partners was captured by the total number of alliances established between the two firms up to the occurrence of the focal alliance. National cultural distance was assessed by a widely-used composite index that was formed based on Hofstede's dimensions of national culture (1980). The index, as illustrated below, computes the score differences along each of the four cultural dimensions (power distance, uncertainty avoidance, masculinity/femininity, and individualism) between the partners' home countries, corrected for the variance of each dimension and then arithmetically averaged.

$$
\mathrm{CD}_{\mathrm{ij}}=\sum_{\mathrm{k}=1-4}\left\{\left(\mathrm{I}_{\mathrm{ki}}-\mathrm{I}_{\mathrm{kj}}\right)^{2} / \mathrm{V}_{\mathrm{k}}\right\} / 4
$$

where $I_{k=1-4}$ are the indices of the four cultural dimensions, $V_{k}$ is the respective variance, and $\mathrm{CD}_{\mathrm{ij}}$ is the cultural distance between the home countries of the two partnering firms.

\section{Results}

Table 3 reports the descriptive statistics of all variables and the correlation matrix. Owing to the binary nature of our dependent variable, we used binomial logistic regression in which positive coefficients signify that independent variables or interaction terms increase the probability that an alliance will choose the equity-based over the nonequity governance structure. Prior to testing the hypothesized relationships, we mean-centered independent variables before creating interaction terms so as to minimize multicollinearity. We sequentially entered control variables, predictors, and interaction terms into hierarchical regression models in order to investigate the incremental explanatory power of the added variables (particularly that of the interaction terms). 
Table 3

\section{Descriptive Statistics and Correlation Matrix}

\begin{tabular}{lccccccc}
\hline Variable & Mean & SD & 1 & 2 & 3 & 4 & 5 \\
\hline 1.Alliance location & 1.25 & .63 & & & & & \\
2. Prior experience & & & & & & & \\
& 2.51 & 3.32 & .01 & & & & \\
3. Cultural distance & 16.88 & 27.74 & .35 & .06 & & & \\
& & & $(.00)$ & $(.49)$ & & & \\
4. Alliance scope & 1.53 & .67 & .07 & -.02 & .01 & & \\
& & & $(.44)$ & $(.81)$ & $(.89)$ & & \\
5. Resource disparity & 2.86 & 27.74 & -.03 & -.04 & -.06 & -.07 & \\
& & & $(.69)$ & $(.62)$ & $(.52)$ & $. .43)$ & \\
6. Market divergence & 1.08 & 1.42 & .08 & -.02 & .02 & .18 & -.06 \\
& & & $(.39)$ & $(.85)$ & $(.79)$ & $(.04)$ & $(.45)$ \\
\hline
\end{tabular}

Note. Significance levels are in the parentheses. All two-tailed tests.

Table 4 reports the results of the regression analyses. Model I is a baseline model that only includes control variables, Model II is a restricted model with predictors added, and Model III is the full model with interaction terms added further. The change in chi-square between Models II (i.e. the restricted model without interaction terms) and III (i.e. the full model) is statistically significant (8.42 at $p \leq 0.01$ ), supporting our general conjecture that the alliance mode choice is influenced by a combination of interpartner differences and collaborative domains.

Table 4

Results of Hierarchical Logistic Regression Analysis (Nonequity = 0 and Equity-based = 1)

\begin{tabular}{lccc}
\hline Variable (hypothesis tested: expected sign) & $\begin{array}{c}\text { Model I } \\
\text { (Controls only) }\end{array}$ & $\begin{array}{c}\text { Model II } \\
\text { (Restricted) }\end{array}$ & $\begin{array}{c}\text { Model III } \\
\text { (Full) }\end{array}$ \\
\hline Control variables: & & & \\
Alliance location & .03 & -.11 & -.23 \\
Prior experience & $(.39)$ & $(.50)$ & $(.55)$ \\
Cultural distance & -.10 & -.15 & -.22 \\
& $(.09)$ & $(.12)$ & $(.14)$ \\
Alliance scope & $.04^{* * *}$ & $.04^{* * *}$ & $.05^{* * *}$ \\
Resource disparity & $(.01)$ & $(.01)$ & $(.01)$ \\
Market divergence & & $1.51^{* *}$ & $2.33^{*}$ \\
& & $(.47)$ & $(.91)$ \\
& & -2.25 & $6.04^{*}$ \\
& & $(1.64)$ & $(2.53)$ \\
& & .12 & -2.32 \\
\hline
\end{tabular}




\section{Table 4 (continued)}

\begin{tabular}{lccc}
\hline Variable (hypothesis tested: expected sign) & $\begin{array}{c}\text { Model I } \\
\text { (Controls only) }\end{array}$ & $\begin{array}{c}\text { Model II } \\
\text { (Restricted) }\end{array}$ & $\begin{array}{c}\text { Model III } \\
\text { (Full) }\end{array}$ \\
\hline Alliance scope $\times$ resource disparity (H1: -$)$ & & & $-6.06^{* *}$ \\
& & & $(2.47)$ \\
Alliance scope $\times$ market divergence (H2: - ) & & & $1.34^{\dagger}$ \\
Model chi-square & $17.06^{* * *}$ & $33.93^{* * *}$ & $(.72)$ \\
Change in model chi-square & & $16.87^{* * *}$ & $42.36^{* * *}$ \\
-2 log likelihood & 82.34 & 65.47 & $8.42^{* *}$ \\
$N$ & 125 & 125 & 57.05 \\
\hline
\end{tabular}

Note. The coefficients are unstandardized. Standard errors are in the parentheses. ${ }^{\dagger} p<0.10 ; * p<0.05 ; * * p<0.01 ; * * * p<0.001$.

With respect to individual moderation effects, Hypothesis 1 postulates that an alliance with smaller interpartner resource disparity and narrower collaborative scope will prefer a nonequity to an equity-based mode. The interaction between alliance scope and resource disparity reported in Table 4 carries a significant and negative sign, as predicted $\left(\beta_{5}=-6.06, p<0.01\right)$. Therefore, Hypothesis 1 is strongly supported. Likewise, Hypothesis 2 posits that an alliance with smaller interpartner market divergence and narrower collaborative scope will choose a nonequity over an equity-based structure. The coefficient for the interaction between alliance scope and market divergence is positive $\left(\beta_{6}=1.34\right.$, $p<0.10$ ), inconsistent with our prediction. Hypothesis 2 is thus not supported.

To further examine the moderating effects, we plot the above findings in Figure 1. Panel (a) confirms Hypothesis 1 that when there is a narrow alliance scope, the probability of choosing an equitybased (a nonequity) alliance is higher for larger (smaller) interfirm resource disparity, while the likelihood of using an equity-based (a nonequity) alliance is lower for larger (smaller) interfirm resource disparity if there is a broad alliance scope. In contrast, Panel (b) shows that in both cases of a narrow or broad alliance scope, the probability of choosing an equity-based (a nonequity) alliance is higher for smaller (larger) interfirm market divergence.

a. Interaction between resource disparity and alliance scope

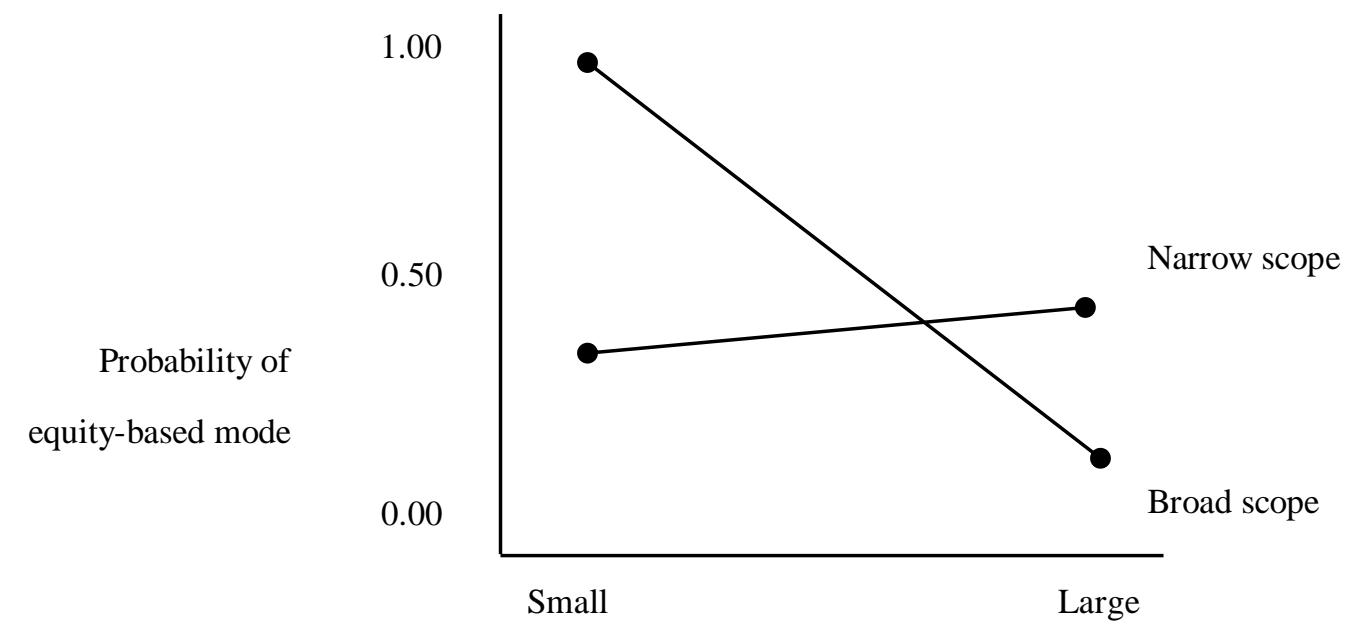

Resource disparity 
b. Interaction between market divergence and alliance scope

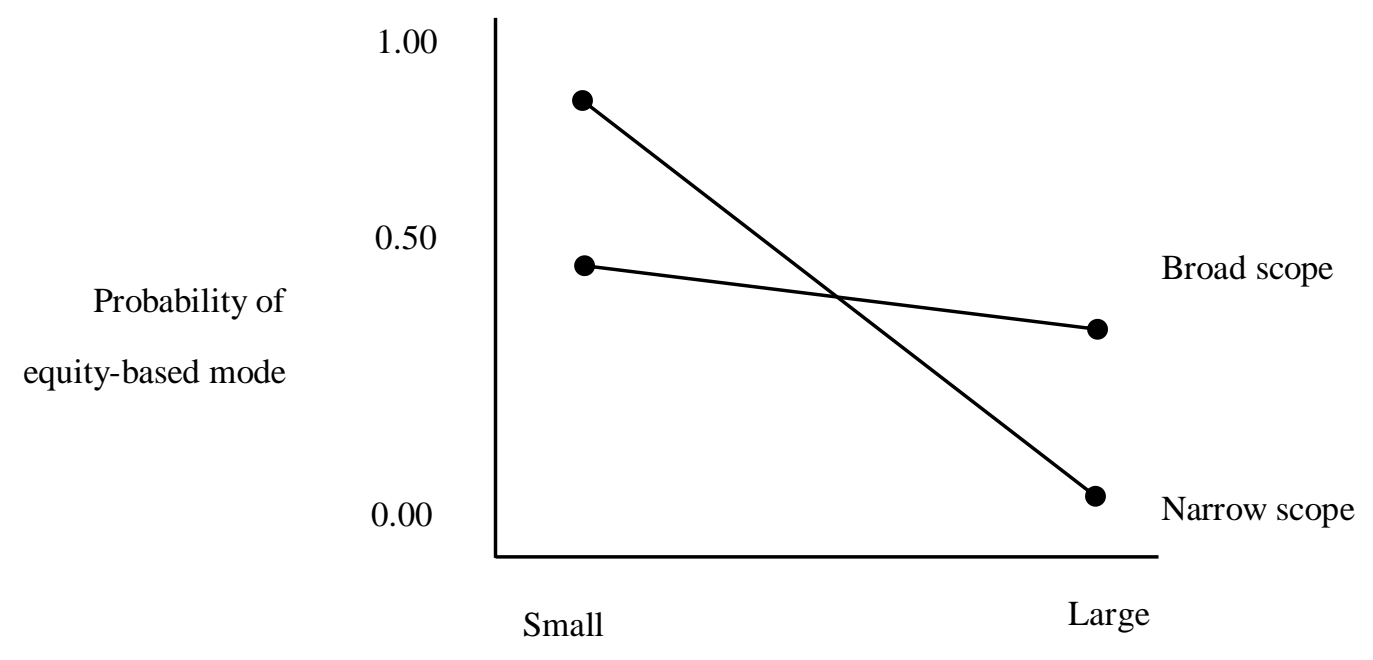

Market divergence

Figure 1. Interaction Plot Exhibiting the Moderation of Alliance Scope

Regarding the control variables, alliance location and previous ties between partners are not significantly related with the nonequity versus equity-based choice across all three regression models. Nevertheless, national cultural distance between the two partners' home countries was found to significantly affect the alliance mode decision, with greater cultural distance tending to result in a preference for an equity-based alliance.

\section{Discussion}

Strategic alliances, characterized by teaming up multiple firms, are a common vehicle through which firms grow and compete. However, this practice has also been described as an inherently unstable organizational form, and often has high dissolution rates owing to interfirm differences, particularly in resource endowment and market coverage, which can pose contractual hazards. As such, it is vital to decide an appropriate alliance mode to better manage interfirm differences. Perhaps surprisingly, previous studies have yielded conflicting guidelines for the choice of alliance mode between the equitybased and nonequity form.

To address this gap in the literature, this study examines how alliance scope influences the extent to which alliance participants exploit interpartner differences to achieve desired objectives, while also being exposed to contractual hazards. The results obtained from 125 strategic alliances confirmed the significant moderating role of alliance scope in the relationship between interfirm differences and alliance mode decision. Specifically, in terms of upstream resource disparity, there is a preference for a nonequity structure for the partnerships that have smaller interfirm differences and narrower alliance scopes while, with respect to downstream market divergence, there is a preference for an equity-based mode.

\section{Contributions to scholarship}

This study has two major contributions to the literature. First, it addresses the ambiguity in prior research on how to tackle interpartner differences using an appropriate alliance mode, in that previous 
studies that ignore alliance scope are likely to capture only one side of the scenario. To our best knowledge, the present research is the first to analyze three important partnering strategies in combination; i.e. whether to ally with partners with fewer or greater differences, whether to restrict or relax the scope of collaborative activities, and whether to opt for an equity-based or a nonequity governance structure. This study echoes D. Li, Eden, Hitt and Ireland (2008) that partner selection (who), governance structure (how), and alliance scope (what) are three integral and closely-related decisions confronting partnering firms, which need to be considered together. Also, the results of this work resonates with Oxley and Sampson (2004), which reported the importance of alliance scope as a governance mechanism to control knowledge-sharing with partners and deal with the issue of opportunism.

Our empirical results support that alliance scope moderates the impact of interfirm differences on the equity-versus-nonequity preference, but the moderation varies between the two types of interfirm differences. This finding contributes to the research stream by showing that, for a small upstream resource difference, narrowing the alliance scope is conducive to protecting firm-specific assets $(e . g$, technological capabilities), and thus a less-costly governance mode; i.e. nonequity form might be sufficient to organize cooperative activities. Nonetheless, the mode choice is the opposite for alliances with a narrow alliance scope and small downstream market divergence, wherein partners are likely to be direct competitors in the marketplace. One possible reason for this surprising finding might be that when a partnership is formed between rivals (i.e. there is small market divergence), a broad alliance scope relative to a narrow one boosts both interdependence and mutual benefits, thus helping curb opportunism due to fears of losing the significant mutual benefits and incurring immediate attacks in the market. In contrast, a narrow alliance scope (e.g., a focus on production expansion project, as described in Garrette, Castaner, \& Dussauge, 2009) is less efficacious for reducing opportunism between direct competitors, and thus there is a need to use an equity-based governance mode.

Second, given that strategic alliances involve multiple firms, several scholars have noted one pronounced drawback of adopting a focal-firm perspective for research on interpartner differences, as this approach simply provides a one-sided analysis of what is clearly a dyadic phenomenon (Wang \& Zajac, 2007; Zajac \& Olsen, 1993). This study moves beyond prior work and responds to this concern by capturing the dyadic characteristics of interfirm upstream resource and downstream market discrepancies from both partners. Based on the logic discussed in previous relevant studies as mentioned in the Methods section, this paper contributes to developing a specific measure for each of the two types of interfirm differences that would be useful for later studies.

\section{Applied implications}

This study also provides practical implications that managers can draw on to manage alliances. To begin with, alliance formation entails several critical decisions. The results of this study suggest that how different a partner is, what range the cooperative activities cover, and how tight the control structure should be are three decisions that need to be considered together. In particular, managers ought to synchronize the first two issues in choosing between an equity-based and a nonequity control mode that is not simply subject to financial availability of their firms. This is especially true when firms have to ally with a specific partner for certain objectives, and do not have too many options with regard to candidate partners. Adjusting alliance scope to minimize the drawbacks brought about by interpartner differences and protect proprietary knowledge is necessary when choosing between an equity-based and a nonequity governance mode.

In addition, previous alliance studies have shed much light on such interfirm differences as cultural fit (e.g., Kim \& Parkhe, 2009; Luo, 2005; Robson, Schlegelmilch, \& Bojkowszky, 2012). This study directs executives to pay more attention to the issues of resource disparity and market divergence. While cultural differences between partners can affect the coordination and success of a specific partnership, the interfirm differences in resource possession and business domains are influential not only on the quality of the cooperation but, more importantly, on the individual partners' competitiveness in the related industry, as noted above. Alliance managers should thus adopt a more comprehensive 
view to evaluate interpartner differences. The findings of this research also show that managers need to be cognizant of the combined effects of alliance scope and different types of interfirm distinctions that lead to different optimal alliance mode choices.

\section{Limitations and future research directions}

The present study has several limitations that also represent directions for future research. First of all, this study aims to examine the governance mode choice of inaugural alliance formation. Accordingly, it focuses purely on the initial condition of a partnership, and does not look into the evolution of the alliance over time. Future scholars can thus investigate whether the alliance mode changes as the cooperation develops. Furthermore, the sample examined in this study is restricted to bilateral alliances, consisting of two partners in the collaboration.

Although it is believed that the insights yielded from this paper should apply to alliances with more than two partners, it remains for later studies to test the current framework in a multilateral setting, where greater complexity among partners may give rise to other cooperative issues. Lastly, this study explains the impact of interfirm differences, combined with the interaction of alliance scope, on the equity-based versus nonequity governance choice from the viewpoint of contractual hazards. Serving as the underlying rationale, contractual hazards were not measured in the current work. Future research may thus incorporate contractual hazards into the model and empirically test their magnitude.

\section{References}

Akerlof, G. A. (1970). The market for lemons: qualitative uncertainty and the market mechanism. The Quarterly Journal of Economics, 84(3), 488-500. http://dx.doi.org/10.2307/1879431

Ang, S. H., \& Michailova, S. (2008). Institutional explanations of cross-border alliance modes: the case of emerging economies firms. Management International Review, 48(5), 551-576. http://dx.doi.org/10.1007/s11575-008-0036-6

Arikan, I., \& Shenkar, O. (2013). National animosity and cross-border alliances. Academy of Management Journal, 56(6), 1516-1544. http://dx.doi.org/10.5465/amj.2011.0210

Choi, J., \& Contractor, F. J. (2016). Choosing an appropriate alliance governance mode: the role of institutional, cultural and geographical distance in international research \& development (R\&D) collaborations. Journal of International Business Studies, 47(2), 210-232. http://dx.doi.org/10.1057/jibs.2015.28

Cohen, W. M., \& Levinthal, D. A. (1990). Absorptive capacity: a new perspective on organization and learning. Administrative Science Quarterly, 35(1), 128-152. http://dx.doi.org/10.2307/2393553

Colombo, M. G. (2003). Alliance form: a test of the contractual and competence perspectives. Strategic Management Journal, 24(12), 1209-1229. http://dx.doi.org/10.1002/smj.353

Das, T. K. (2006). Strategic alliance temporalities and partner opportunism. British Journal of Management, 17(1), 1-21. http://dx.doi.org/10.1111/j.1467-8551.2006.00482.x

Das, T. K., \& Teng, B.-S. (2003). Partner analysis and alliance performance. Scandinavian Journal of Management, 19(3), 279-308. http://dx.doi.org/10.1016/S0956-5221(03)00003-4

Davis, J. P. (in press). The group dynamics of interorganizational relationships: collaborating with multiple partners in innovation ecosystems. Administrative Science Quarterly. 
Diestre, L., \& Rajagopalan, N. (2011). An environmental perspective on diversification: the effect of chemical relatedness and regulatory sanctions. Academy of Management Journal, 54(1), 97-115. http://dx.doi.org/10.5465/AMJ.2011.59215087

Dyer, J. H. (1996). Does governance matter? Keiretsu alliances and asset specificity as sources of Japanese competitive advantage. Organization Science, 7(6), 649-666. http://dx.doi.org/10.1287/orsc.7.6.649

García-Canal, E., Valdés-Llaneza, A., \& Sánchez-Lorda, P. (2014). Contractual form in repeated alliances with the same partner: the role of inter-organizational routines. Scandinavian Journal of Management, 30(1), 51-64. http://dx.doi.org/10.1016\%2Fj.scaman.2013.06.001

Garrette, B., Castaner, X., \& Dussauge, P. (2009). Horizontal alliances as an alternative to autonomous production: Product expansion mode choice in the worldwide aircraft industry 1945-2000. Strategic Management Journal, 30(8), 1213-1233. http://dx.doi.org/10.1002/smj.770

Gulati, R., Lavie, D., \& Singh, H. (2009). The nature of partnering experience and the gains from alliances. Strategic Management Journal, 30(11), 885-894. http://dx.doi.org/10.1002/smj.786

Gulati, R., \& Singh, H. (1998). The architecture of cooperation: managing coordination costs and appropriation concerns in strategic alliances. Administrative Science Quarterly, 43(4), 781-814. http://dx.doi.org/10.2307/2393616

Hannan, M. T., \& Freeman, J. H. (1977). The population ecology of organizations. American Journal of Sociology, 82(5), 929-964. http://dx.doi.org/10.1086/226424

Hennart, J.-F. (1988). A transaction cost theory of equity joint ventures. Strategic Management Journal, 9(4), 361-374. http://dx.doi.org/10.1002/smj.4250090406

Hoetker, G., \& Mellewigt, T. (2009). Choice and performance of governance mechanisms: matching alliance governance to asset type. Strategic Management Journal, 30(10), 1025-1044. http://dx.doi.org/10.1002/smj.775

Hofstede, G. (1980). Culture's consequences: international differences in work-related values. Beverly Hills, CA: Sage.

Holloway, S. S., \& Parmigiani, A. (2016). Friends and profits don't mix: the performance implications of repeated partnerships. Academy of Management Journal, 59(2), 460-478. http://dx.doi.org/10.5465/amj.2013.0581

Holmstrom, B. (1979). Moral hazard and observability. The Bell Journal of Economics, 10(1), 74-91. http://dx.doi.org/10.2307/3003320

Holmstrom, B., \& Roberts, J. (1998). The boundaries of the firm revisited. Journal of Economic Perspectives, 12(4), 73-94. http://dx.doi.org/10.1257/jep.12.4.73

Judge, W. Q., \& Dooley, R. (2006). Strategic alliance outcomes: a transaction-cost economics perspective. British Journal of Management, 17(1), 23-37. http://dx.doi.org/10.1111/j.14678551.2005.00441.x

Kayo, E. K., Kimura, H., Patrocínio, M. R., \& Oliveira, L. E., Neto (2010). Acquisitions, joint ventures or arm's-length alliances? Analyzing the determinants of the choice of growth strategy in Brazil from 1996 through 2007. Brazilian Administration Review, 7(4), 397-412. Retrieved from http://www.scielo.br/pdf/bar/v7n4/06.pdf. http://dx.doi.org/10.1590/S180776922010000400006 
Khanna, T., Gulati, R., \& Nohria, N. (1998). The dynamics of learning alliances: competition, cooperation, and relative scope. Strategic Management Journal, 19(3), 193-210. http://dx.doi.org/10.1002/(SICI)1097-0266(199803)19:3<193::AID-SMJ949>3.0.CO;2-C

Kim, J., \& Parkhe, A. (2009). Competing and cooperating similarity in global strategic alliances: an exploratory examination. British Journal of Management, 20(3), 363-376. http://dx.doi.org/10.1111/j.1467-8551.2008.00580.x

Klein, B., Crawford, R. G., \& Alchian, A. A. (1978). Vertical integration, appropriable rents, and the competitive contracting process. The Journal of Law and Economics, 21(2), 297-326. http://dx.doi.org/10.1086/466922

Kogut, B. (1988). Joint ventures: theoretical and empirical perspectives. Strategic Management Journal, 9(4), 319-332. http://dx.doi.org/10.1002/smj.4250090403

Lazzarini, S. G., Brito, L. A. L., \& Chaddad, F. R. (2013). Conduits of innovation or imitation? Assessing the effect of alliances on the persistence of profits in U.S. firms. Brazilian Administration Review, 10(1), 1-17. Retrieved from http://www.scielo.br/pdf/bar/v10n1/aop0112.pdf. $\quad$ http://dx.doi.org/10.1590/S180776922012005000001

Lee, J., Hoetker, G., \& Qualls, W. (2015). Alliance experience and governance flexibility. Organization Science, 26(5), 1536-1551. http://dx.doi.org/10.1287/orsc.2015.0989

Lee, G. K., \& Lieberman, M. B. (2010). Acquisition vs. internal development as modes of market entry. Strategic Management Journal, 31(2), 140-158. http://dx.doi.org/10.1002/smj.804

Li, N., Boulding, W., \& Staelin, R. (2010). General alliance experience, uncertainty, and marketing alliance governance mode choice. Journal of the Academy of Marketing Science, 38(2), 141-158. http://dx.doi.org/10.1007/s11747-009-0154-0

Li, D., Eden, L., Hitt, M., \& Ireland, R. D. (2008). Friends, acquaintances or strangers? Partner selection in R\&D alliances. Academy of Management Journal, 51(2), 315-334. http://dx.doi.org/10.5465/AMJ.2008.31767271

Lioukas, C. S., Reuer, J. J., \& Zollo, M. (2016). Effects of information technology capabilities on strategic alliances: implications for the resource-based view. Journal of Management Studies, 53(2), 161-183. http://dx.doi.org/10.1111/joms.12179

Luo, Y. (2005). How important are shared perceptions of procedural justice in cooperative alliances? $\begin{array}{llll}\text { Academy of } & \text { Management }\end{array}$ http://dx.doi.org/10.5465/AMJ.2005.17843946

Mayer, K. J., \& Salomon, R. M. (2006). Capabilities, contractual hazards, and governance: integrating resource-based and transaction cost perspectives. Academy of Management Journal, 49(5), 942959. http://dx.doi.org/10.5465/AMJ.2006.22798175

Mitchell, W., Dussauge, P., \& Garrette, B. (2002). Alliances with competitors: how to combine and protect key resources. Journal of Creativity and Innovation Management, 11(3), 1-21. http://dx.doi.org/10.1111/1467-8691.00253

Osborn, R. N., \& Baughn, C. C. (1990). Forms of interorganizational governance for multinational alliances. Academy of Management Journal, 33(3), 503-519. http://dx.doi.org/10.2307/256578

Oxley, J. E. (1997). Appropriability hazards and governance in strategic alliances: a transaction cost approach. The Journal of Law, Economics, and Organization, 13(2), 387-409. http://dx.doi.org/10.1093/oxfordjournals.jleo.a023389 
Oxley, J. E. (1999). Institutional environment and the mechanisms of governance: the impact of intellectual property protection on the structure of inter-firm alliances. Journal of Economic Behavior and Organization, 38(3), 283-309. http://dx.doi.org./10.1016/S0167-2681(99)00011-6

Oxley, J. E., \& Sampson, R. C. (2004). The scope and governance of international R\&D alliances. Strategic Management Journal, 25(8-9), 723-749. http://dx.doi.org/10.1002/smj.391

Pangarkar, N., \& Klein, S. (2001). The impacts of alliance purpose and partner similarity on alliance governance. British Journal of Management, 12(4), 341-353. http://dx.doi.org/10.1111/14678551.00214

Pehrsson, A. (2006). Business relatedness and performance: a study of managerial perceptions. Strategic Management Journal, 27(3), 265-282. http://dx.doi.org/10.1002/smj.516

Pisano, G. P. (1989). Using equity participation to support exchange: evidence from the biotechnology industry. Journal of Law, Economics, and Organization, 5(1), 109-126.

Polidoro, F., Jr., Ahuja, G., \& Mitchell, W. (2011). When the social structure overshadows competitive incentives: the effects of network embeddedness on joint venture dissolution. Academy of Management Journal, 54(1), 203-223. http://dx.doi.org/10.5465/AMJ.2011.59215088

Reuer, J. J., \& Devarakonda, S. V. (2016). Mechanisms of hybrid governance: administrative committees in non-equity alliances. Academy of Management Journal, 59(2), 510-533. http://dx.doi.org/10.5465/amj.2012.0098

Robson, M. J., Schlegelmilch, B. B., \& Bojkowszky, B. (2012). Resource deployment stability and performance in international research-and-development alliances: a self-determination theory explanation. Journal of International Marketing, 20(1), 1-18. http://dx.doi.org/10.1509/jim.11.0072

Sampson, R. C. (2004). Organizational choice in R\&D alliances: knowledge-based and transaction cost perspectives. Managerial and Decision Economics, 25(6-7), 421-436. http://dx.doi.org/10.1002/mde.1199

Shen, W., \& Cannella, A. A., Jr. (2002). Revisiting the performance consequences of CEO succession: the impact of successor type, postsuccession senior executive turnover, and departing CEO tenure. Academy of Management Journal, 45(4), 717-733. http://dx.doi.org/10.2307/3069306

Silva, G., Dacorso, A. L. R., Costa, V. B., \& Di Serio, L. C. D. (2016). Relationships and partnerships in small companies: strengthening the business through external agents. Brazilian Administration Review, 13(1), 1-18. Retrieved from http://www.scielo.br/pdf/bar/v13n1/1807-7692-bar0116.pdf. http://dx.doi.org/10.1590/1807-7692barnaahead0116

Simonin, B. L. (1999). Ambiguity and the process of knowledge transfer in strategic alliances. Strategic Management Journal, 20(7), 595-623. http://dx.doi.org./10.1002/(SICI)10970266(199907)20:7<595::AID-SMJ47>3.0.CO;2-5

Singh, H., Kryscynski, D., Li, X., \& Gopal, R. (2016). Pipes, pools, and filters: how collaboration networks affect innovative performance. Strategic Management Journal, 37(8), 1649-1665. http://dx.doi.org/10.1002/smj.2419

Stern, I., Dukerich, J. M., \& Zajac, E. (2014). Unmixed signals: how reputation and status affect alliance formation. Strategic Management Journal, 35(4), 512-531. http://dx.doi.org/10.1002/smj.2116

Teece, D. J. (1986). Profiting from technological innovation: implications for integration, collaboration, licensing, and public policy. Research Policy, 15(6), 285-305. http://dx.doi.org/10.1016/00487333(86)90027-2 
Teece, D. J. (1992). Competition, cooperation, and innovation. Journal of Economic Behavior and Organization, 18(1), 1-25. http://dx.doi.org/10.1016/0167-2681(92)90050-L

Tyler, B. B., \& Caner, T. (2016). Net product introductions below aspirations, slack and R\&D alliances: a behavioral perspective. Strategic Management Journal, 37(5), 896-910. http://dx.doi.org/ $10.1002 /$ smj. 2367

Varadarajan, P. R., \& Cunningham, M. H. (1995). Strategic alliances: a synthesis of conceptual foundations. Journal of the Academy of Marketing Science, 23, 282-296. http://dx.doi.org/10.1177/009207039502300408

Wang, L., \& Zajac, E. J. (2007). Alliance or acquisition? A dyadic perspective on interfirm resource combinations. Strategic Management Journal, 28(13), 1291-1317. http://dx.doi.org/10.1002/smj.638

Williamson, O. E. (1975). Market and hierarchies: analysis and anti-trust implications. A study in the economics of internal organization. New York: Free Press.

Williamson, O. E. (1985). The economic institutions of capitalism. New York: Free Press.

Yang, H., Lin, Z., \& Lin, Y. (2010). A multilevel framework of firm boundaries: firm characteristics, dyadic differences, and network attributes. Strategic Management Journal, 31(3), 237-261. http://dx.doi.org/10.1002/smj.815

Zajac, E. J., \& Olsen, C. P. (1993). From transaction cost to transactional value analysis: implications for the study of interorganizational strategies. Journal of Management Studies, 30(1), 131-145. http://dx.doi.org/10.1111/j.1467-6486.1993.tb00298.x

\section{Author's Profile}

Chiung-Hui Tseng

National Cheng Kung University, 1, University Road, Tainan, 70101, Taiwan. E-mail address: ctseng@ mail.ncku.edu.tw 